\title{
Pengaruh Audit Eksternal terhadap Pelaksanaan Laporan Koperasi Unit Desa
}

\author{
AFRIJAL \\ Universitas Pasir Pangaraian (UPP) \\ J1.Tuanku Tambusai, Kumu Desa Rambah, Kec. Rambah Hilir, Kab. Rokan Hulu, Riau \\ Tel : (0762) 7392272; Fax : (0762) 7392273 \\ E-mail :afrijalrauf@yahoo.com
}

\begin{abstract}
KUD report provides an overview of the quality rather than the board KUD, the admissibility of this report is crucial penguru management in the future. This condition is the part that needs to be observed, because the reporting is done the board is still not optimal. Through a survey conducted to 93 members KUD in Kampar provide prove that the role of external auditors in reporting KUD to members of the cooperative itself. Pengaruhn positive and significant impact on the quality of reporting is leading the auditor to audit the implementation neutrality
\end{abstract}

Keywords: External Audit, Reporting KUD

Laporan akhir tahun atau dikenal di masyarakat perkoperasian adalah dengan singkatan RAT menjadi salah satu bentuk kinerja pengurus koperasi dalam rangka mempertanggungjawabkan kinerja perkoperasian yang diurusnya. RAT ini dilaksanakan selama setahun sekali dan memuat hasil kerja dalam terutama dalam sisi keuangan. Banyak terdapat persoalan dimana RAT ini masih dipertanyakan keabsahannya atau kejujuran daripada RAT ini sendiri. Kemudian juga sebagian anggota koperasi selalunya mengukur keberhasilan pengurus ini daripada wajah RAT yang dilakukan diakhir tahun.

Untuk menyusun laporan koperasi yang dilakukan pada acara RAT ini akan menjadi masa depan dari pengurus yang sedang bertugas apakah akan diterima oleh anggota atau tidak bisa diterimanya. Kondisi ini membuat laporan akhir tahun menjadi suatu yang sangat diinginkan untuk dilaksanakan baik oleh pengurus yang mempunyai tanggungjawab dan tugasnya maupun oleh anggota koperasi yang ingin tahu perkembangan koperasi selama ini.

Kabupaten Kampar adalah salah satu daerah yang memiliki konsentrasi koperasi terbesar di Propinsi Riau, permasalahan umum koperasi di daerah ini adalah kinerja koperasi khususnya bila dilihat dari rapat anggota tahunan (RAT) yang diselenggarakan dalam rangka mempertanggungjawabkan kepengurusan pengurus kepada anggota yang telah memberikan kepercayaan kepada pengurus untuk mengelola koperasi.

sebagian besar koperasi tidak aktif, kemudian pengurus kurang berpengalaman yang hanya 3 - 5 tahun, sedangkan karyawan merupakan karyawan yang sudah cukup berpengalaman yakni 5-10 tahun dan pedidikan rata-rata pengurus adalah SMA dan karyawannya juga SMA. Di Kabupaten Kampar terdapat 21 Kecamatan diantaranya tersebar sebanyak 475 unit koperasi yang aktif sebanyak 379 dan yang tidak aktif sebanyak 96 koperasi. Koperasi terbanyak terdapat di Kecamatan Tapung yang berjumlah 52 unit koperasi di tahun 2013. Koperasi tersebut yang memiliki produk yang kompetitif sesuai dengan kebutuhan konsumen dan layanan yang prima.

Jumlah KUD di Kecamatan Tapung mengalami penurunan sebesar $15.8 \%$. Dilihat dari juga mengalami penurunan dan juga karyawanya. Permasalahan yang muncul dari segi layanan pada konsumen baik layanan produk atau jasa adalah bagaimana memberikan pelayanan yang berkualitas dan memuaskan mengingat setiap koperasi memiliki karakteristik atau keunggulan tersediri dari segi produk dan jasanya. 
Kualitas jasa semata-mata ditentukan konsumen / anggota, sehingga kepuasan konsumen hanya dapat dicapai dengan memberikan kualitas yang baik.

Pada artikel ini dibahas mengenai peran daripada kualitas audit eksternal terhadap laporan koperasi unit desa dalam rangka pencapaiannya dan memberikan dan meyakinkan anggota koperasi terhadap hasil kepengurusannya. Kaitannya dengan audit eksternal yaitu dihubungkan dengan laporan yang disusun apakah sudah bekerjasama dengan audit eksternal dalam hal perhitungan dan pertanggungjawabannya sehingga lebih mantap dan lebih dapat dipertanggungjawabkan.

Beberapa pendapat ahli berkaitan dengan masalah audit ekternal dan juga masalah pelaporan dari pertanggungjawaban perkoperasian. Kusharyanti (2003:25), kualitas audit adalah kemungkinan (joint probability) dimana seorang auditor akan menemukan dan melaporkan pelanggaran yang ada dalam sistem akuntansi kliennya. Deis dan Giroux (1992) mengungkapkan terdapat empat hal yang dianggap mempunyai hubungan dengan kualitas audit yaitu (1) Lama waktu auditor telah melakukan pemeriksaan terhadap suatu perusahaan (tenure), (2) Jumlah klien, (3) Kesehatan keuangan klien, dan (4) Review oleh pihak ketiga. Sedangkan Alim et al. (2007) meneliti 7 atribut yang dapat dijadikan ukuran dalam mengukur kualitas audit, yaitu (1) Deteksi salah saji, (2) Kesesuaian dengan SPAP, (3) Kepatuhan terhadap SOP, (4) Risiko Audit, (5) Prinsip kehati-hatian, (6) Proses pengendalian atas pekerjaan oleh supervisor, dan (7) Perhatian yang diberikan oleh manajer atau partner. Penelitian tersebut menghasilkan kesimpulan, bahwa ketujuh atribut tersebut dapat digunakan dalam mengukur kualitas audit.

Palmrose (1988) mendefinisikan kualitas audit sebagai suatu tingkat kepastian atau jaminan. Ketika tujuan dari suatu audit adalah memberikan jaminan atas laporan keuangan, kemungkinan kualitas audit atas laporan keuangan berisi laporan salah saji yang tidak material. Dalam kenyataannya, definisi ini menggunakan hasil -hasil audit, yaitu reliabilitas dari laporan keuangan yang telah diaudit menggambarkan kualitas auditnya. Definisi ini menyebabkan pertanyaan-pertanyaan sebagai berikut “ bagaimana pengguna laporan keuangan menilai tingkat kepastian dan reliabilitas dari laporan keuangan yang telah diaudit?" hal ini merupakan suatu kualitas audit yang post hoc dikarenakan tingkat kepastian atau jaminan tidak dapat dinilai sampai audit selesai dilakukan.

Kualitas audit diartikan sebagai probabilitas seorang auditor dimana dapat menentukan dan melaporkan penyelewengan yang terjadi dalam sistem akuntansi klien (Christina, 2003). DeAngelo (1981) mendefinisikan kualitas audit sebagai "pasar menilai kemungkinan bahwa auditor akan memberikan : a). Penemuan mengenai suatu pelanggaran dalam sistem akuntansi klien; dan b). Adanya pelanggaran dalam pencatatannya ". Kemungkinan bahwa auditor akan melaporkan adanya laporan yang salah saji telah dideteksi dan didefinisikan oleh DeAnggelo (1981) sebagai independensi auditor.

Menurut Marxen (1990), buruknya kualitas audit disebabkan oleh beberapa perilaku disfungsional, yaitu: Underreporting of time, premature sign off, altering/replacement of audit procedure. Underreporting of time menyebabkan keputusan personel yang kurang baik, menutupi kebutuhan revisi anggaran, dan menghasilkan time pressure untuk audit di masa datang yang tidak di ketahui. Premature sign-off (PMSO) merupakan suatu keadaan yang menunjukkan auditor menghentikan satu atau beberapa langkah audit yang diperlukan dalam prosedur audit tanpa menggantikan dengan langkah yang lain. Sedangkan altering/replacing of audit procedure adalah penggantian prosedur audit yang seharusnya yang telah ditetapkan dalam standar auditing.

Independensi adalah sesuatu hal yang harus dipertahankan pada saat auditor melakukan audit. Independensi merupakan pedoman bagi auditor maka jika dalam 
melaksanakan kerja auditor tidak independen opini yang diberikan dalam laporan keuangan tidak bermanfaat untuk pengguna laporan keuangan. Prinsip independensi oleh seorang auditor merupakan faktor penting dalam peningkatan profesionalisme (Meigs et al., 1997; AISG, 1976). Auditor harus independen dari setiap kewajiban atau independen dari pemilikan kepentingan dalam perusahaan yang diauditnya.

Independensi adalah suatu istilah yang sering digunakan oleh profesional auditor. Arens dan Loebbecke (1991), mengatakan bahwa independensi auditor berarti cara pandang yang tidak memihak di dalam penyelenggaraan pengujian audit, evaluasi hasil audit, dan penyusunan laporan audit. Antle (1984) mendefinisikan independensi sebagai suatu hubungan antara akuntan dan kliennya yang mempunyai sifat sedemikian rupa sehingga temuan dan laporan yang diberikan oleh auditor hanya dipengaruhi oleh bukti-bukti yang ditemukan dan dikumpulkan sesuai dengan aturan atau prinsip profesionalnya.

Hasil penelitian mengenai independensi yang telah dilakukan oleh Alim et, al. (2007) mengemukakan bahwa tidak mudah menjaga tingkat independensi agar tetap sesuai dengan jalur yang seharusnya. Kerjasama dengan klien yang terlalu lama bisa menimbulkan kerawanan atas independensi yang dimiliki oleh auditor. Belum lagi berbagai fasilitas yang disediakan klien selama penugasan audit untuk auditor. Bukan tidak mungkin, auditor menjadi "mudah dikendalikan" klien karena auditor berada dalam posisi yang dilematis.

\section{METODE}

Penelitian ini menggunakan metode survey, dalam pengumpulan datanya menggunakan kuesioner yang disebarkan kepada anggota KUD, yaitu anggota KUD di Kecamatan Tapung yang berjumlah 16 unit KUD dan diambil sebanyak 3 KUD yaitu berdasarkan UU No 17 Tahun 2000 tentang Pajak Penghasilan yang membagi KUD ke dalam tiga kelompok, yakni kelompok KUD yang memiliki SHU kurang dari Rp. 50 juta tergolong KUD kecil dan tidak dikenakan pajak badan, kemudian KUD yang memiliki SHU antara Rp. 50 juta s/d Rp. 100 juta yakni KUD menengah dan KUD yang memiliki SHU lebih dari Rp. 100 juta atau KUD besar. Sampel diambil menggunakan teknik proporsional random sampling (Sugiyono, 2008). Besarnya sampel ditetapkan dengan menggunakan rumus slovin sebanyak 93 orang dari 1.290 anggota KUD. Data dianalisis dengan menggunakan analisis kuantitatif dengan rumus regresi linier sederhana.

\section{HASIL}

Berdasarkan hasil penelitian sebagaimana disampaikan bahwa terdapat pengaruh yang siginfikan peran auditor ekternal terhadap laporan koperasi unit desa yang dapat dipaparkan pada hasil penelitian sebagai berikut:

Tabel 1: Model Summary

\begin{tabular}{|l|r|r|r|r|}
\hline Model & R & R Square & $\begin{array}{c}\text { Adjusted R } \\
\text { Square }\end{array}$ & $\begin{array}{c}\text { Std. Error of } \\
\text { the Estimate }\end{array}$ \\
\hline 1 & $.632^{\mathrm{s}}$ & .399 & .393 & .49368 \\
\hline
\end{tabular}

a. Predictors: (Constant), audit ekstemal

Pada tabel 1 di atas dapat dijelaskan bahwa pengaruh audit eksternal sebesar $63,2 \%$ terhadap laporan KUD dalam menyakinkan anggota koperasi dalam hal kepengurusannya sebagai pengurus KUD. Selanjutnya juga dapat dilihat data berikut berkaitan dengan nilai pengaruh audit ekternal terhadap laporan KUD sebagai berikut:

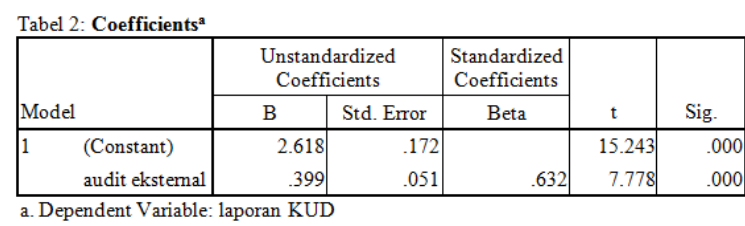

Dari data tersebut di atas, dapat diketahui bahwa audit eksternal memberikan pengaruh positif dan signifikan, dengan nilai pengaruh sebesar 0,399 berarti bahwa semakin baik kualitas audit ekternal dalam melakukan penilaian terhadap pelaporan KUD maka akan berkualita pula KUD dalam melaporkan hasil kerja dalam RAT. Kemudian diketahui juga bahwa setiap peningkatan satu satuan kualitas audit 
ekternal maka akan meningkatkan kualitas laporan KUD sebesar 0,399 satuan. Selain itu juga juga terbukti bahwa audit eksternal berpengaruh signifikan $($ sign $<0,000)$ terhadap laporan KUD kepada anggotanya pada RAT.

\section{PEMBAHASAN}

RAT (Rapat Anggota Tahunan) dalam KUD (Koperasi Unit Desa) pemegang kekuasaan tertinggi dalam koperasi. Tetapi bukan berarti rapat anggota bersifat tak tebatas. Kekuasaan tertinggi suatu rapat anggota tetap ada batasnya yaitu prinsip koperasi dan peraturan perundang-undangan yang berlaku. Sehingga jika misalnyarapat anggota mengambil keputusan yang bertentangan dengan prinsip koperasi dan perundang-undangan yang berlaku maka keputusan itu akan gugur. Menurut pasal 23 Undang-Undang Nomor 17 Tahun 2012, rapat anggota menetapkan: 1) Anggaran dasar; 2) Kebijakan umum; 3) Pemilihan, pengangkatan, pembwerhentian pengurus dan pengawasan; 4) Rencana kerja, rencana anggaran pendapatan dan belanja koperasi serta pengesahan laporan keuangan; 5) Pengesahan pertanggungjawaban pengurus dalam pelaksanaan tugasnya; 6) Pembagian sisa hasil usaha; 7) Penggabungan, peleburan, pembagian dan pembubaran koperasi.

Secara hukum rapat anggota koperasi adalah pemilik dari kopeasi dan usahanya, dan anggotalah yang mempunyai wewenang mengendalikan koperasi bukan pengurus dan bukan pula manajer. Oleh karena itu tidaklah salah kalau dikatakan bahwa kunci dari keberhasilan koperasi terletak pada anggota. Para anggota koperasi bertemu pada waktuwaktu pada suatu rapat, yang selanjutnya disebut Rapat Anggota, waktu-waktu mana telah diatur dalam Anggaran Dasar / Anggaran Rumah Tangga.

Rapat anggota mempunyai kekuasaan tertinggi dalam organisasi koperasi. Tetapi sebagaimana telah dikatakan diatas, Rapat Anggota itu adalah tempat dimana suara-suara anggota berkumpul dan hanya diadakan pada waktu-waktu tertentu. Oleh karena itu, disamping kita membahas peranan dari Rapat
Anggota dalam manajemen koperasi perlu pula kita membahas sejauh mana anggota koperasi perorangan itu ikut berpartisipasi dalam manajemen koperasi.

Pengurus KUD dalam rangka mempertanggungjawabkan kepengurusannya perlu mengikutsertakan auditor dari luar sehingga laporan yang disampaikan pada RAT ini akan mudah dimengerti dan mendapatkan keyakinan dari anggota KUD sendiri. Independensi auditor juga menjadi barometer dalam laporan KUD itu sendiri. Sebagaimana dijelaskan dari hasil penelitian Alim (2007) terdapat pengaruh kompetensi terhadap kualitas auditor, terdapat pengaruh independensi terhadap kualitas auditor, terdapat pengaruh etika terhadap hubungan antara independensi dengan kualitas auditor, tidak ada pengaruh etika terhadap hubungan antara kompetensi dengan kualitas auditor. Ini menunjukkan hubungan yang erat dalam rangka menghasilkan laporan KUD yang berkualitas.

\section{SIMPULAN}

Dari hasil uraian di atas, maka dapat diketahui bahwa peran audit ekternal dalam rangka menghasilkan laporan KUD yang berkualitas itu sangat besar, peran ini juga sangat bergantung daripada indenpendensi audtor dalam melaksanakan audir. Pengaruh positif peran auditor terhadap laporan memberikan gambaran bahwa seoranga auditor harus benar-benar netral dalam menilai sebuah laporan sehingga kinerja KUD dapat dipertanggungjawabkan di masa depan.

\section{DAFTAR RUJUKAN}

Kusharyanti, 2003, Kualitas Audit dan Kemungkinan Topik Penelitian di Masa Datang. Jurnal Akuntansi dan Manajemen (Desember). Hal 25-60

Palmrose, 1988, An Analysis of Auditor Litigation and Audit Service Quality. The Accounting Review (January): 55-73 
Christina, 2003, Pengaruh Kompetensi dan Independensi Auditor terhadap Kualitas Audit. Skripsi. Universitas Negeri Semarang.

DeAngelo, 1981, Auditor Independence, "Low Balling", and DisclosureRregulation. Journal of Accounting and Economics . August. pp. 113-127.

Marxen, 1990, Determination of DPPH Radical Oxidation Caused by Methanolic Extracts of Some Microalgal Species by Linear Regression Analysis of Spectrophotometric Measurements. Sensors 7: 2080-2095.

Meigs et al., 1997, Principle of Auditing, New York:John Willey \& Sons Inc.
Antle, 1984, Auditor Independence. Journal of Accounting Research.

Alim et, al, 2007, Pengaruh Kompetensi dan Independensi terhadap Kualitas Audit dengan Etika Auditor sebagai variabel Moderasi. Simposium Nasional Akuntansi X Makasar

Sugiyono, 2008, Metode Penelitian Kuantitatif, Kualitatif dan $R \& D$. Alfabeta, Bandung

Undang-Undang Nomor 17 Tahun 2012 tentang Perkoperasian 